\title{
INVENTARISASI DAERAH RAWAN LONGSOR KABUPATEN BANJARNEGARA JAWA TENGAH
}

\author{
Warnadi \\ Dosen Jurusan Geografi FIS UNJ \\ E-mail : warnadiandi@yahoo.co.id
}

\begin{abstract}
This Research aims to inventory landslide-prone areas in Banjarnegara district, Central Java. The study was conducted between May-September 2012. The method used in this research is descriptive quantitative method with a spatial approach. Technical analysis of the data in this study is the use overlay of several variables landslides, the data is then entered into the data input software program Arc View. The data is processed, then is the determination of landslide prone areas using Storie index Broadly speaking causative factor.a landslides) geological conditions such as weathered rock, soil layers slope, earthquakes and volcanic eruptions.b) Climate namely when high rainfall .c) topography is steep slopes. Pagenten subdistricts and districts Pandanarum including the high risk of avalanche danger. This can be evidenced by the number of landslides that often occur, particularly in the village of Tlaga (Pandanarum district) and Mundasari village and village in the district Suwidak Pagenten. Subdistrict Wanayasa, Batur, Banjarmangu, Kalibening and Sigaluh is a district that includes categorized as being the average of 4-6 landslide each year. Region of relatively light among other avalanche events in the Pejawaran district, Banjarnegara, Pagedongan, Lampok, and Purwanegara with only 2-4 landslide each year.
\end{abstract}

Keywords: Inventory landslide-prone areas, Banjarnegara, Central Java.

\section{PENDAHULUAN}

Hampir semua pulau utama di Indonesia memiliki beberapa kabupaten dan kota yang rawan pergerakan tanah, setidaknya terdapat 918 lokasi rawan longsor di Indonesia. Daerah rawan longsor di Indonesia adalah: Jawa Tengah 327 Lokasi, Jawa Barat 276 Lokasi, Sumatera Barat 100 Lokasi, Sumatera Utara 53 Lokasi, Yogyakarta 30 Lokasi, Kalimantan Barat 23 Lokasi, Sisanya tersebar di NTT, Riau, Kalimantan Timur, Bali, dan Jawa Timur.

Dalam tahun 2011, Potensi bencana terutama tanah longsor terjadi di 154 kabupaten/kota rawan tanah longsor (gerakan tanah). Bulan Januari sampai Maret merupakan puncak atau terjadi anomali cuaca yang sangat tinggi sehingga sangat memungkinkan terjadinya banjir dan tanah longsor diberbagai wilayah di Indonesia. Tempat-tempat yang rawan harus menjadi perhatian pemerintah daerah dan segera menyusun rencana kontijens sebagai bentuk kesiapsiagaan dan kewaspadaan dalam menghadapi bencana gerakan tanah.

Propinsi Jawa Tengah adalah satu diantara propinsi dengan tingkat tertinggi rawan gerakan tanah di Indonesia. Kabupaten Banjarnegara dan Wonosobo dimana seluruh kecamatan di kedua kabupaten tersebut memiliki tingkat rawan longsor yang tinggi dibanding kabupaten lainnya. Berdasarkan kejadian tersebut diatas, maka diperlukan adanya upaya peningkatan kesiapsiagaan masyarakat dan daerah dalam menghadapi kemungkinan terjadinya ancaman gerakan tanah tersebut.

\section{METODOLOGI PENELITIAN}

Tujuan penelitian ini adalah untuk Inventarisasi wilayah rawan longsor di Kabupaten Banjarnegara, Jawa Tengah. Penelitian dilakukan antara Bulan MeiSeptember 2012 bertempat di Kabupaten Banjarnegara, Provinsi Jawa Tengah. Metode yang yang digunakan dalam penelitian ini adalah metode deskriptif kuantitatif dengan pendekatan spasial. Data utama yang digunakan dalam penelitian ini antara lain adalah : Peta rupa bumi Kab. Banjarnegara, Peta jenis tanah Kab Banjarnegara yang diperoleh dari Badan Informasi Geospasial $(B I G)$, Data sekunder yang berkaitan dengan 
data kependudukan yang diperoleh dari monografi desa atau Data Potensi Desa (Podes). Teknis analisis data dalam penelitian ini adalah menggunakan teknik tumpangsusun (overlay) dari beberapa variabel longsor, antara lain kemiringan lereng, curah hujan, jenis tanah, kepadatan penduduk. Dengan Sistem Informasi Geografi (SIG), data tersebut kemudian di masukkan kedalam input data software program Arc View.Setelah data diproses, kemudian dilakukan penentuan daerah rawan longsor dengan menggunakan indeks Storie, yaitu pengalian dari setiap parameter longsor. Rumus yang digunakan adalah:

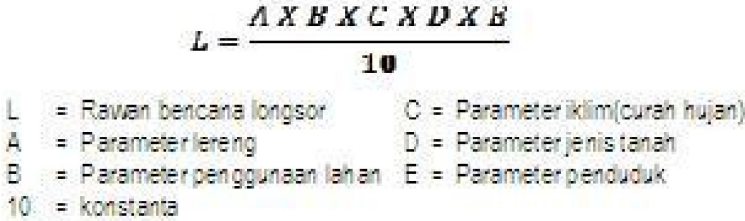

Setelah semua parameter dimasukkan ke dalam rumus storie, maka selanjutnya adalah penentuan kelas tingkatan longsor yang

disesuaikan dengan kebutuhan. Kelas tingkatan longsor dalam penelitian ini dibagi menjadi 4 (empat) kelas.

Tabel 1. Klasifikasi Daerah Rawan Longsor

\begin{tabular}{ccc}
\hline No & Klasifikasi & Kisaran Nilai \\
\hline 1 & Rendah & $0-15$ \\
2 & Sedang & $16-40$ \\
3 & Tinggi & $41-60$ \\
4 & Sangat tinggi & $>60$ \\
\hline
\end{tabular}

Sumber: Perhitungan rumus Storie

HASIL PENELITIAN

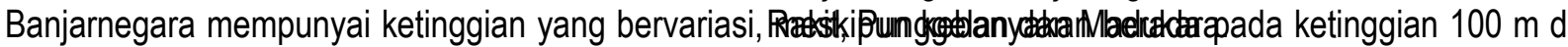
hanya seluas $9,82 \%$ saja. Adapun ketinggian topografi setiap daerah di Kabupaten Banjarnegara adalah sebagai berikut :

1. Kurang dari 100 mdpl meliputi luas $9,82 \%$ dari luas wilayah Kabupaten yang meliputi Kecamatan Susukan, Purworejo Klampok, Mandiraja, Purwonegoro dan Bawang.

2. Antara $100-500$ mdpl, meliputi luas 37,04 $\%$ luas wilayah Kabupaten Banjarnegara yang meliputi Kecamatan Susukan, Mandiraja, Purwonegoro, Bawang,
Banjarmangu, Banjarnegara, Wanadadi,

3. Antara $500-1.000 \mathrm{mdpl}$, meliputi luas 28,74 $\%$ dari luas wilayah Kabupaten Banjarnegara, yang meliputi Kecamatan Banjarmangu, Sigaluh dan sebagian Banjarnegara.

4. Lebih dari $1.000 \mathrm{mdpl}$, meliputi luas $24,4 \%$ dari luas wilayah Kabupaten Banjarnegara, yang meliputi Kecamatan Karangkobar, Wanayasa, Kalibening, Pagentan, Pejawaran dan Batur. 


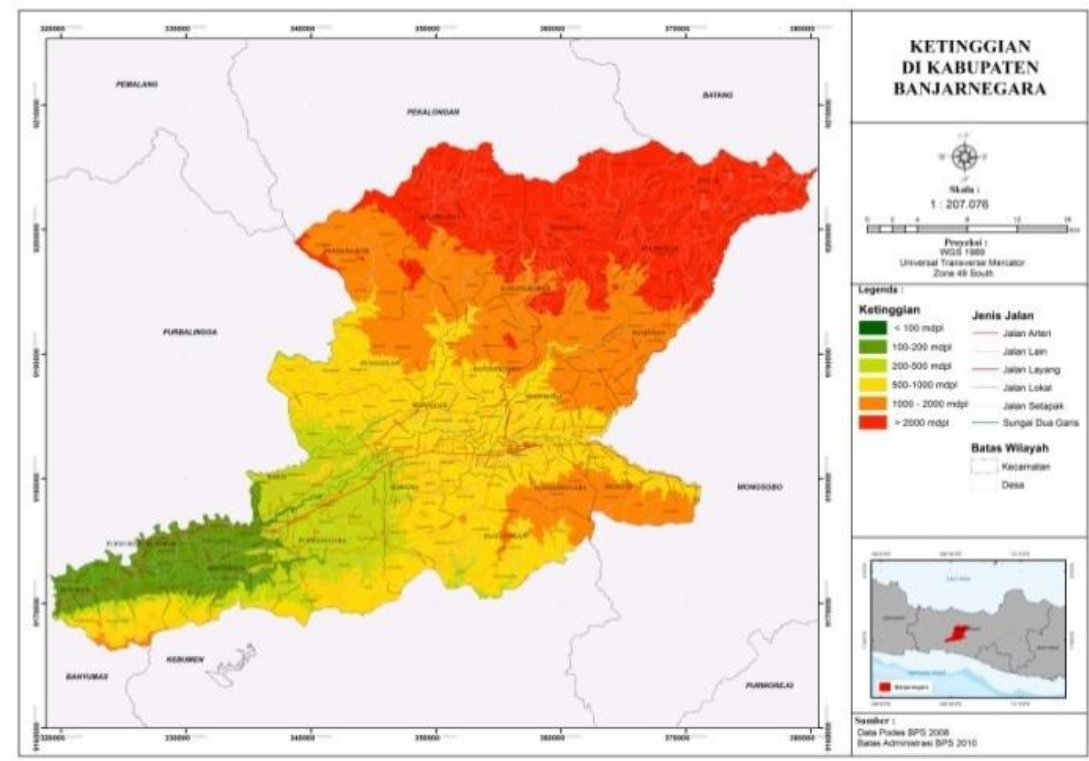

Gambar 1. Peta Ketinggian Kabupaten Banjarnegara

Ditinjau dari segi kemiringan, dapat dibedakan menjadi 3 (tiga) kemiringan, yaitu:

1. Antara $0-15 \%$ meliputi luas $24,6 \%$ dari luas wilayah Kabupaten banjarnegara yang meliputi Kecamatan Susukan, Purworejo Klampok, Mandiraja, Purwanegara, Pagedongan, Bawang dan Rakit.

2. Diatas $15-40 \%$, meliputi luas $45,04 \%$ dari luas wilayah kabupaten Banjarnegara yang meliputi Kecamatan Madukara, Banjarmangu, Wanadadi, Punggelan,
Karangkobar, Pagentan, Wanayasa dan Kalibening.

3. Lebih dari $40 \%$ meliputi luas $30,35 \%$ dari luas wilayah Kabupaten Banjarnegara meliputi Kecamatan Susukan, Banjarnegara, Sigaluh, Banjarmangu, Pejawaran dan Batur.

4.

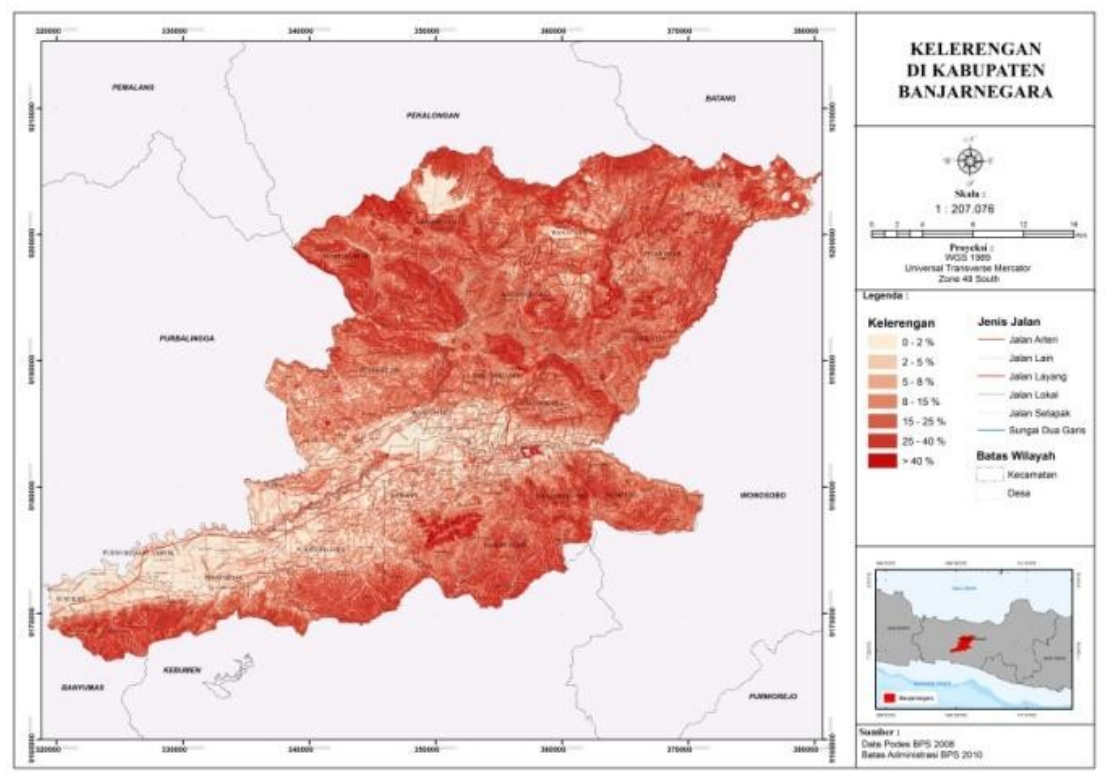

Gambar 2. Peta Kemiringan Lereng Kabupaten Banjarnegara 


\section{Kondisi Geologi}

Kondisi geologi meliputi: struktur geologi, yang kemudian akan menentukan jenis tanah. Kedua hal ini sangat menentukan dan berpengaruh pada kondisi lingkungan fisik di Kabupaten Banjarnegara. Berdasarkan peta geologi Kabupaten Banjarnegara dapat dijelaskan mengenai kondisi geologi sebagai berikut :

a. Pembagian Formasi Endapan

Berdasarkan hasil survey nasional tentang geologi regional, Kabupaten Banjarnegara termasuk wilayah jalur fisiografi pegunungan Serayu Selatan. Adapun Stratigrafi Daerah terdiri dari batuan yang tertua yaitu batuan molion (metamorf) yang terdiri dari Sekis Kristalin, Sabak, Serpil Hitam, Filit, Kwarsit dan batuan batu Gamping.

\section{b. Formasi Batuan}

Formasi batuan di Kabupaten Banjarnegara adalah sebagai berikut: Batuan Grewake dan Lempung Hitam tersingkap di daerah Kalitengah sampai Merden, Batuan Metasedimen tersingkap di daerah Kalitengah hingga daerah Kebutuhan Duwur, Batuan Filit dan Sekis singkapannya banyak ditemukan di lereng selatan pegunungan Serayu Selatan.

Berdasarkan kondisi geologi yang ada, berikut adalah tabel yang menunjukkan sebaran jenis tanah yang ada di Kabupeten Banjarnegara.

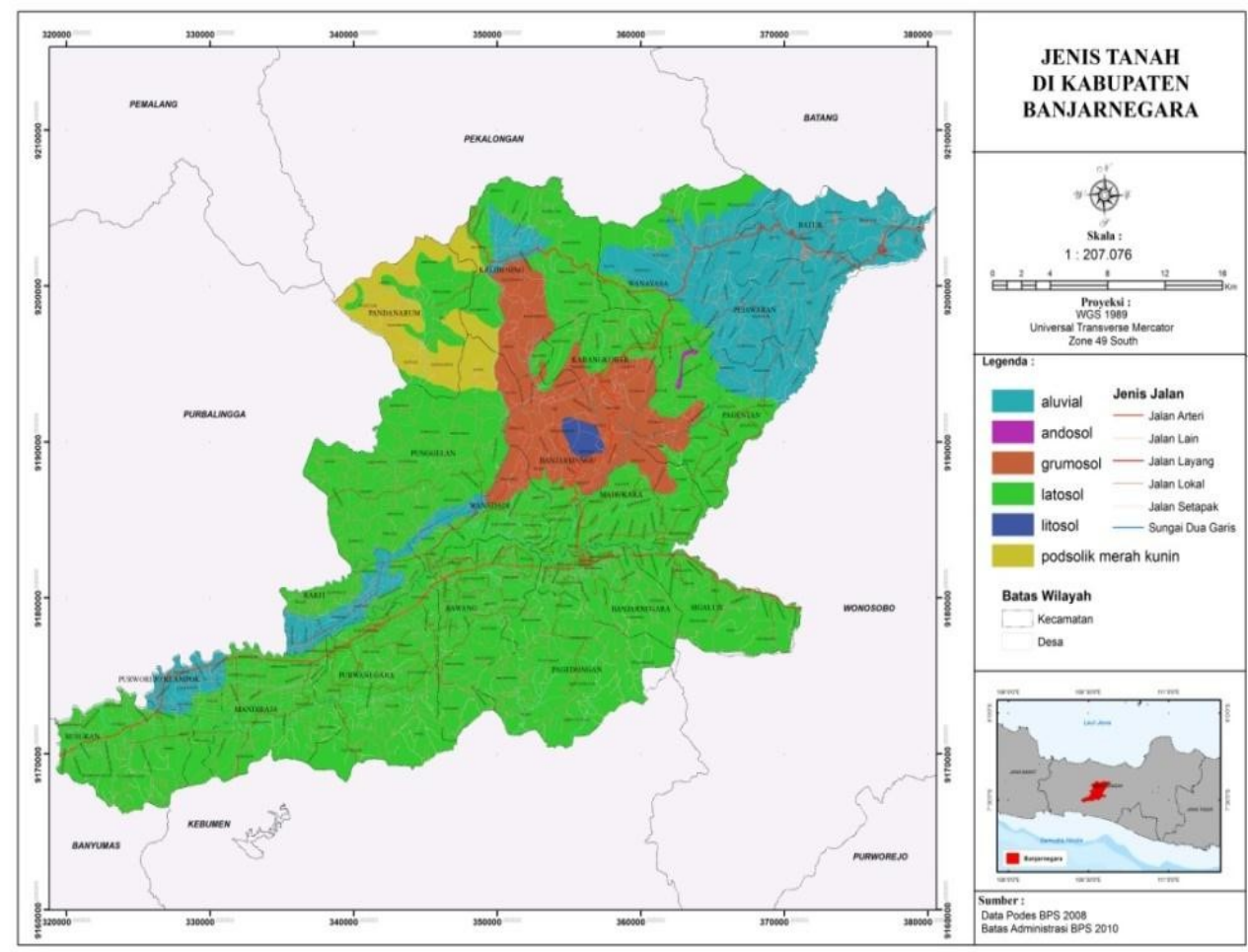

Gambar 3 Peta Sebaran Tanah Kabupaten Banjarnegara

Kondisi klimatologi Kabupaten Banjarnegara seperti halnya kebanyakan wilayah di Indonesia yang beriklim tropis, dengan bulan basah umumnya lebih banyak daripada bulan kering. Temperatur udara berkisar antara $20-26^{\circ} \mathrm{C}$, temperatur terdingin yaitu $3-18^{\circ} \mathrm{C}$ dengan temperatur terdingin tercatat pada musim kemarau di Dataran Tinggi Dieng. Kelembaban udara berkisar antara $80 \%-85 \%$ dengan curah hujan tertinggi ratarata $3.000 \mathrm{~mm} /$ tahun. Semakin tinggi tempat itu dari permukaan air laut, maka curah hujan dan frekuwensi hujannya semakin tinggi. Pada umumnya bulan basah terjadi antara Bulan 
September-Maret, sedangkan bulan kering berkisar antara April-Agustus. Puncak musim hujan berada pada Bulan Desember-Januari. Kabupaten Banjarnegara bagian utara merupakan wilayah yang memiliki curah hujan yang paling tinggi dibandingkan dengan wilayah tengah maupun selatan. Berikut adalah gambaran sebaran rata-rata curah hujan di Banjarnegara. Peta sebaran curah hujan pada gambar di bawah ini.

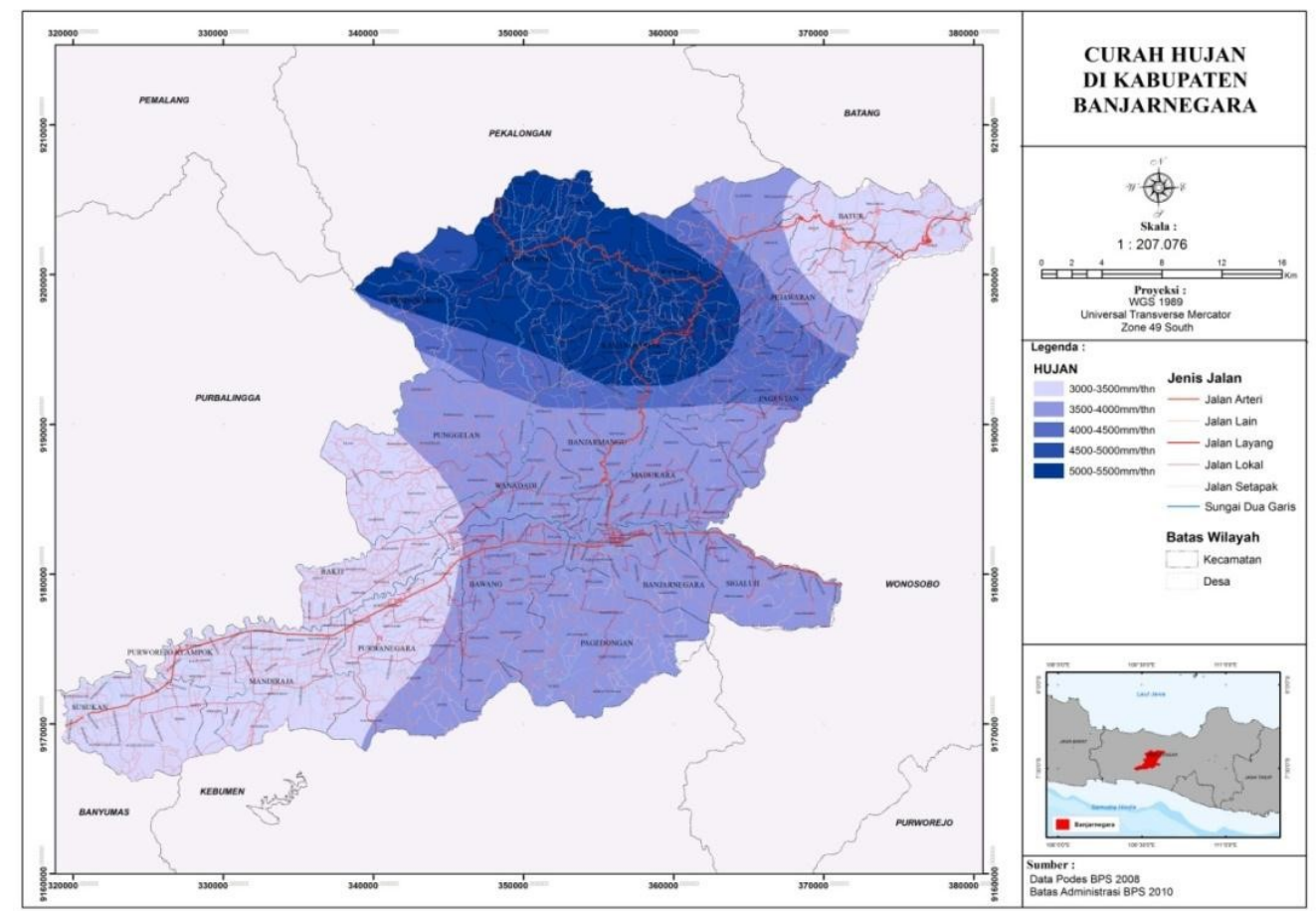

Gambar 6 Peta Sebaran Curah Hujan Kabupaten Banjarnegara.

Apabila dilihat dari peta diatas, makan curah hujan yang tinggi justru berada pada daerah perbukitan dengan tingkat kelerengan yang tinggi. Sebaliknya, curah hujan dengan intensitas rendah berada pada daerah dataran rendah.

\section{Demografi}

Penduduk akhir tahun 2010 sebanyak 932.668 jiwa, terdiri dari 466.410 laki-laki dan 466.278 perempuan, yang berarti mengalami kenaikan sebesar 7.027 jiwa atau sebesar 0,76 persen dari jumlah penduduk akhir tahun 2009 sebanyak 925.661 jiwa. Kepadatan penduduk akhir tahun 2010 sebesar 872 jiwa per km². Seiring bertambahnya jumlah penduduk, terjadi pula peningkatan jumlah rumah tangga yang diakibatkan oleh perubahan status perkawinan penduduk. Jika pada akhir tahun 2009 jumlah rumah tangga yang ada tercatat 243.696 rumah tangga dan akhir tahun 2010 menjadi 245.242 rumah tangga, dengan kata lain terjadi kenaikan jumlah rumah tangga sebanyak 1.546 rumah tangga atau sebesar 0,63 persen. Kecamatan Banjarnegara, Purworejo Klampok dan Rakit adalah kecamatan dengan tingkat kepadatan penduduk tertinggi, masing-masing dengan jumlah kepadatan 2.323 jiwa per km2, 2.209 jiwa per $\mathrm{km}^{2}$ dan 1.584 jiwa perkm². Sedangkan kecamatan yang tingkat kepadatan penduduknya rendah adalah Kecamatan Pandanarum dan Kecamatan Pagedongan, yakni sebesar 378 per $\mathrm{km}^{2}$ dan 457 per $\mathrm{km}^{2}$. Kepadatan rumah tangga menurut kecamatan, tertinggi adalah Kecamatan Banjarnegara, Purworejo, Klampok dan Rakit dengan kepadatan sebesar 554 rumah tangga per $\mathrm{km}^{2}$, 529 rumah tangga per $\mathrm{km}^{2}$ dan 455 rumah tangga per $\mathrm{km}^{2}$. Adapun kecamatan dengan kepadatan rumah tangga terendah adalah Kecamatan Pandanarum sebesar 109 rumah tangga per $\mathrm{km}^{2}$ dan Pagedongan sebesar 110 rumah tangga per $\mathrm{km}^{2}$. 


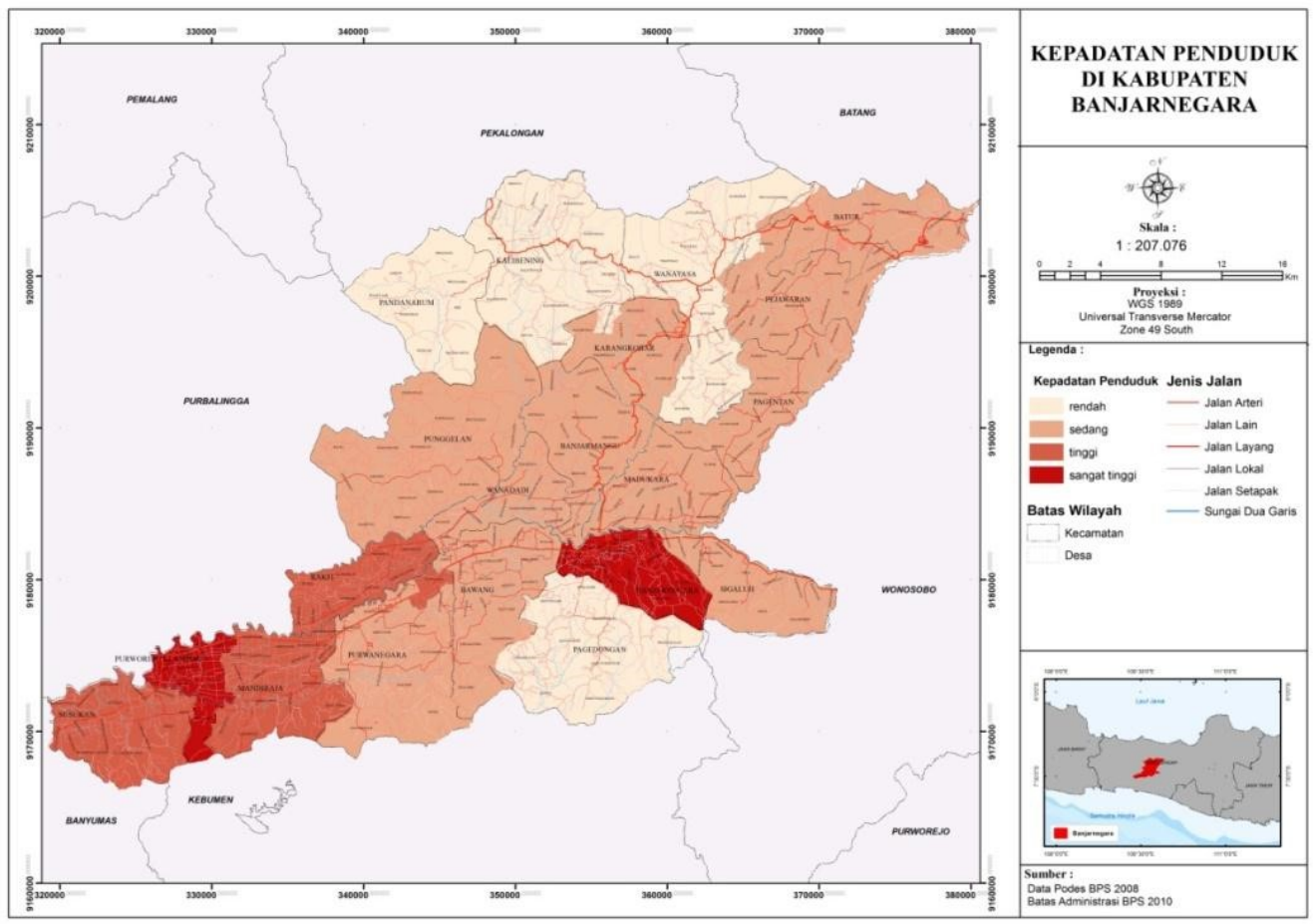

Gambar 7. Peta Kepadatan Penduduk Kabupaten Banjarnegara

\section{Perekonomian}

Selama tahun 2010, luas panen padi sawah di Kab. Banjarnegara mencapai 25.028 ha, mengalami peningkatan sebesar 2,89\% dibanding dengan tahun 2009. Walaupun ada peningkatan luas panen, namun produksi padi sawah turun sebesar 2,84\% dibandingkan tahun 2009. Produktivitas padi sawah selama tahun 2010 turun disbanding tahun 2009 yaitu sebesar 57,4 Kw/ha. Pada komoditas padi ladang, pada tahun 2010 terjadi peningkatan luas panen mencapai 885 ha, atau 63,30\% sedangkan untuk tingkat produktivitas juga terjadi kenaikan menjadi 36,88 kw/ha. Jika dilihat lebih rinci menurut kecamatan, terdapat 8 kecamatan yang mengalami tingkat produktivitas padi yang lebih tinggi daripada tingkat rata-rata produksi kabupaten yang mencapai 55,69 kw/ha. Dari kedelapan kecamatan tersebut kecamatan yang mempunyai tingkat produktivitas tertinggi yaitu Kecamatan Banjarnegara sebesar 60,98 kw/ha.
Tanaman jagung di Kab. Banjarnegara selama tahun 2010 mengalami penurunan luas panen sebesar $6,77 \%$, demikian juga dalam produksi juga mengalami penurunan sebesar $3,43 \%$, sedangkan untuk tingkat produktivitas tanaman jagung mengalami kenaikan sebesar 3,59\%. Jika dibandingkan dengan hasil produksi tanaman perkebunan pada tahun 2009, pada tahun 2010 produksi kapulaga, kapuk randu, glagah arjuna, cengkeh dan kopi mengalami kenaikan. Sedangkan produksi mlati gambir, aren, lada, kina, kemukus, kayu manis, klapa deres, klapa hibrida dan klapa dalam mengalami penurunan produksi. Untuk tanaman hutan rakyat di Kabupaten Banjarnegara selama tahun 2010 tidak mengalami perubahan luas area tanaman jika dibandingkan dengan tahun 2009. Sedangkan untuk produksi kehutanan baik berupa kayu bulat maupun kayu olahan mengalami penurunan hasil produksi. 


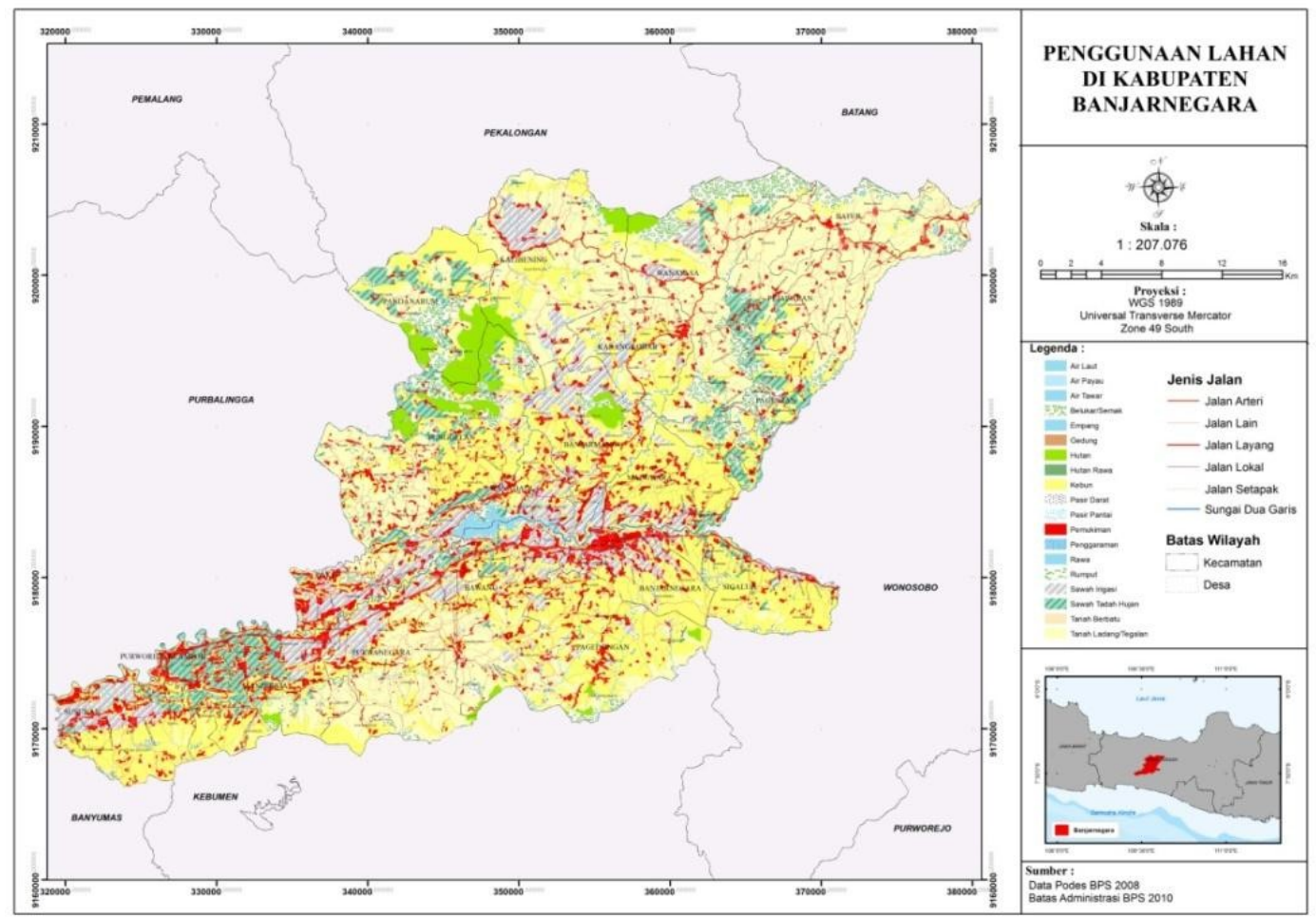

Gambar 8. Peta Penggunaan Lahan Kabupaten Banjarnegara

Dampak dari kondisi geografis dan proses geologi yang ada, maka Kabupaten Banjarnegara sangat potensial terjadi gerakan tanah atau longsor. Beberapa peristiwa longsor dalam skala ringan sampai berat pernah terjadi di sini, hingga yang paling fenomenal adalah longsor di Desa Sijeruk Kecamatan Banjarmangu yang merenggut 76 korban jiwa. Selain korban jiwa, tanah longsor mengakibtkan pula kerugian materi harta benda. Longsor pada tahun 2009 dengan frekuensi longsor 126 kali, yang berdampak pada kerusakan lahan pertanian dan permukiman dengan nilai krugian mencapai 1 miliar.

Faktor utama penyebab longsor adalah lereng, disamping curah hujan dan jenis tanah. Tabel berikut adalah gambaran umum wilayah Kabupaten Banjarnegara dengan kelerengannya.

Tabel 2. Kelerengan Wilayah Kabupaten Banjarnegara

\begin{tabular}{|c|c|c|c|c|}
\hline No & Kelerengan & $\mathrm{Kec}$ & natan & Keterangan \\
\hline 1. & Antara 0-15\% & $\begin{array}{l}\text { - Susukan } \\
\text { - Purworejo Klampok } \\
\text { - Mandiraja } \\
\text { - Purwanegara }\end{array}$ & $\begin{array}{l}\text { - Pagedongan } \\
\text { - Bawang } \\
\text { - Rakit }\end{array}$ & $\begin{array}{l}\text { luas } 24,61 \% \text { dari luas } \\
\text { wilayah Kabupaten } \\
\text { banjarnegara }\end{array}$ \\
\hline 2. & Diatas $15-40 \%$ & $\begin{array}{l}\text { - Madukara } \\
\text { - Banjarmangu } \\
\text { - Wanadadi } \\
\text { - Punggelan }\end{array}$ & $\begin{array}{l}\text { - Karangkobar } \\
\text { - Pagentan } \\
\text { - Wanayasa } \\
\text { - Kalibening }\end{array}$ & $\begin{array}{l}\text { meliputi luas } 45,04 \% \\
\text { dari luas wilayah } \\
\text { kabupaten } \\
\text { Banjarnegara }\end{array}$ \\
\hline 3. & Lebih dari $40 \%$ & $\begin{array}{l}\text { - Susukan } \\
\text { - Banjarnegara } \\
\text { - Sigaluh }\end{array}$ & $\begin{array}{l}\text { - Banjarmangu } \\
\text { - Pejawaran } \\
\text { - Batur }\end{array}$ & $\begin{array}{l}\text { luas } 30,35 \% \text { dari luas } \\
\text { wilayah Kabupaten } \\
\text { Banjarnegara }\end{array}$ \\
\hline
\end{tabular}

Sumber: Kabupaten Banjarnegara dalam angka thn 2010 
Dari tabel diatas tampak bahwa hanya sebagian kecil saja wilayah dengan kelerengan $0 \%-8 \%$. Sebagian besar $(70 \%)$ wilayah di Kabupaten ini (di sebelah utara) berada pada kelerengan $15 \%$ - $\leq 40 \%$. Kondisi semacam ini, ditambah dengan curah hujan yang tinggi, serta penggunaan lahan yang kurang tepat, berpotensi terjafi gerakan tanah atau longsor.

Curah hujan, baik intensitas dan durasinya merupakan salah satu faktor penyebab terjadinya longsor. Curah hujan di Kabupaten Banjarnegara rata-rata sebesar $3202 \mathrm{~mm}$ pertahun dengan jumlah hari hujan rata-rata 230 hari hujan pertahun. Kondisi ini cukup potensial untuk memicu adanya gerakan tanah atau longsor. Kombinasi antara kelerengan, jenis tanah, dan curah hujan akan menghasilkan peta rawan longsor seperti pada gambar dibawah ini.

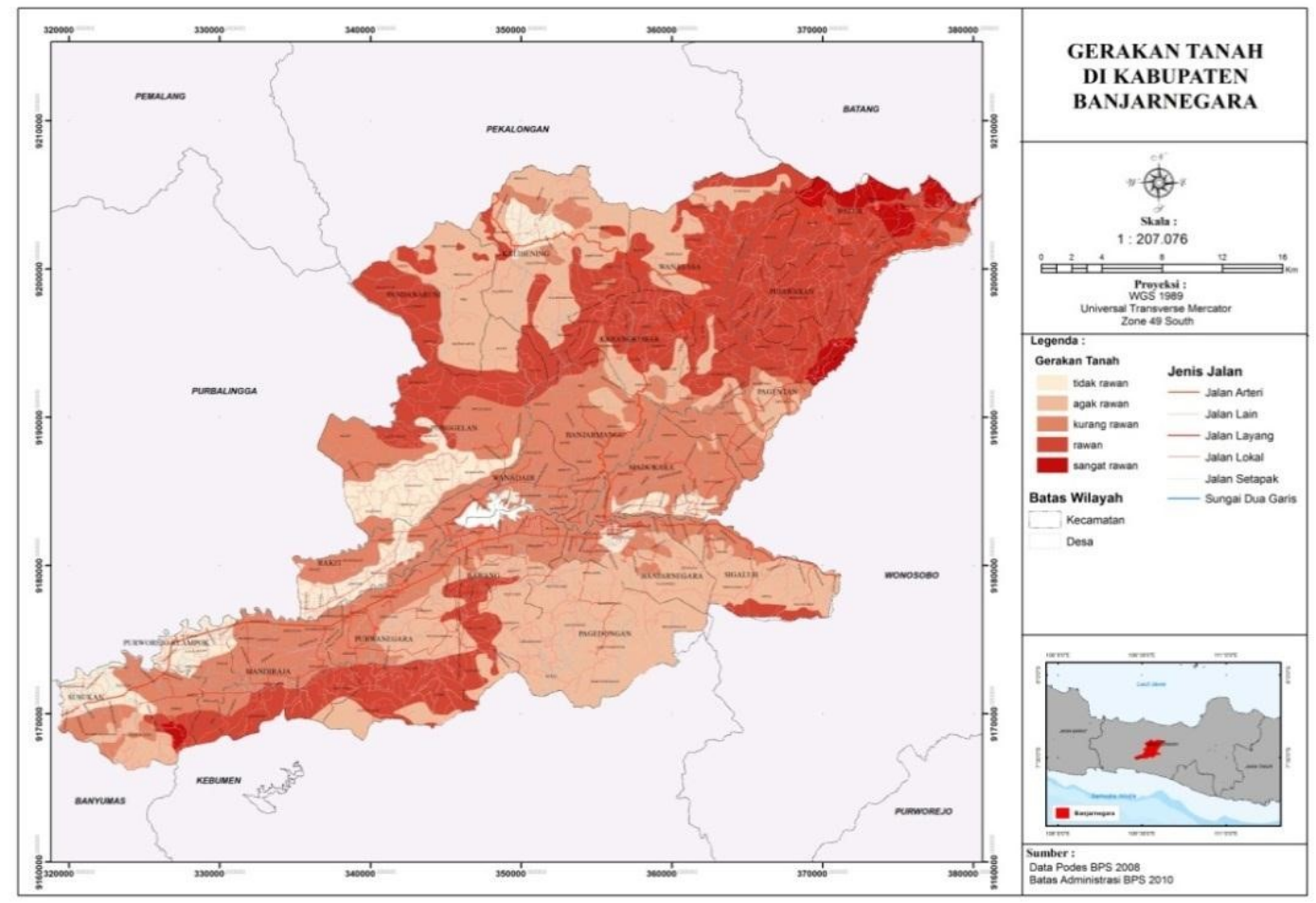

Gambar 9. Peta Penggunaan Lahan Kabupaten Banjarnegara

\section{Gerakan Tanah (Longsor)}

Hasil pemetaan lapangan dan analisa citra satelit menunjukkan bahwa zona kerentanan tinggi terkonsentrasi terutama di daerah-daerah utara Banjarnegara dan Karangkobar pada litologi satuan breksi volkanik (produk G.Jimbangan), breksi dari Formasi Tapak, dan batupasir tufaan Formasi Halang dan pada satuan lempung napalan dari Formasi Rambatan yang mempunyai sifat ekspansif. Juga pada zona struktur patahan dan kontak satuan batuan breksi dengan satuan sedimen (Formasi Rambatan - Formasi Halang dan Breksi gunungapi).

Wilayah Jawa Tengah khususnya Banjarnegara-Karangkobar mempunyai sejarah yang panjang akan permasalahan gerakan tanah. Mitigasi bencana gerakan tanah atau longsoran memerlukan upaya pemahaman sebaran zona-zona bencana geologi tersebut, dan aspek geologi yang menjadi faktor terjadinya longsoran, seperti kondisi geologi, topografi, hidrologi, curah hujan dan sifat keteknikan material tanah/batuan. Hasil pemetaan lapangan dan analisa citra satelit menunjukkan bahwa zona kerentanan tinggi terkonsentrasi terutama di daerah-daerah utara Banjarnegara dan Karangkobar pada litologi satuan breksi volkanik (produk G.Jimbangan), breksi dari Formasi Tapak, dan batupasir tufaan Formasi Halang dan pada satuan lempung napalan dari Formasi 
Rambatan yang mempunyai sifat ekspansif. Juga pada zona struktur patahan dan kontak satuan batuan breksi dengan satuan sedimen (Formasi Rambatan- Formasi Halang dan Breksi gunung api).

Daerah Banjarnegara dan sekitarnya merupakan kawasan yang mempunyai frekwensi terjadinya gerakan tanah yang cukup tinggi di bandingkan dengan daerah lain di Jawa Tengah. Daerah yang sangat rawan terjadinya gerakan tanah dijumpai pada kawasan Banjarnegara bagian utara, hal ini ditunjukkan oleh morfologi/topografi yang sebagian besar mempunyai sudut lereng $>30$. Jenis batuan penyusun yang terdiri dari batulempung, breksi, batupasir dari Formasi rambatan juga sangat berpengaruh terhadap terjadinya gerakan tanah di kawasan ini. Berdasarkan hal ini telah dilakukan penelitian dan pengkajian terhadap badan jalan di kawasan rumah pembangkit (power house) yang mengalami longsor. Hasil pengamatan lapangan menunjukkan bahwa badan jalan yang longsor terdapat pada satuan batulempung, batu lanau dan napal dari formasi Rambatan.

Di bagian atas dari lokasi longsoran dijumpai retakan-retakan yang mudah terisi air, sehingga dapat memicu longsoran. Pengukuran sondir menunjukkan bahwa daerah transisi antara tanah yang lunak dan keras yang di-interpretasikan sebagai bidang gelincir dijumpai pada kedalaman 2 meter. Hasil perhitungan curah hujan pemicu gerakan tanah dicirikan oleh nilai ambang intensitas curah hujan sebesar $42 \mathrm{~mm} / \mathrm{jam}$ dengan durasi 2,08 jam dengan total hujan sebesar $87,84 \mathrm{~mm}$. Hasil perhitungan tersebut diperlihatkan dalam bentuk kurva hubungan antara intensitas curah hujan dan waktu durasi hujan. Pengamatan lapangan juga dilakukan pada pintu keluar terowongan pipa pesat yang memberikan indikasi gejala longsor pada dinding saluran tersebut.

Tabel 3. Potensi Gerakan Tanah (Longsor) Kabupaten Banjarnegara

\begin{tabular}{clll}
\hline No. & \multicolumn{1}{c}{ Kecamatan } & \multicolumn{1}{c}{ Desa } & \multicolumn{1}{c}{ Potensi Gerakan Tanah } \\
\hline 1. & Karangkobar & & Menengah - Tinggi \\
2. & Wanadadi & & Menengah \\
3. & Banjarnegara & Desa Kemranggon, Kedawung & Menengah \\
4. & Susukan & Menengah - Tinggi \\
5. & Wanayasa & Desa Wanayasa dan Desa Susukan & Menengah \\
6. & Purwonegoro & Desa Purwonegoro dan Mertasari Wetan & Menengah - Tinggi \\
7. & Purworejo Klampok & & Menengah \\
8. & Mandiraja & & Menengah - Tinggi \\
9. & Bawang & & Menengah - Tinggi \\
10. & Banjarmangu & Desa Kalilunjar, Banjarmangu dan & Menengah - Tinggi \\
11. & Kalibening & Banjarkulon & Menengah - Tinggi \\
12. & Batur & Desa Maja Tengah & Menengah - Tinggi \\
13. & Pagentan & & Menengah - Tinggi \\
14. & Rakit & Desa Pagentan dan Metawana & Menengah - Tinggi \\
15. & Madukara & & Menengah - Tinggi \\
16. & Pejawaran & Desa Talunamba, Pekauman dan & Menengah - Tinggi \\
17. & Sigaluh & Madukara & Menengah - Tinggi \\
18. & Punggelan & Desa Prigi dan Bojanegara & Menengah - Tinggi \\
\hline
\end{tabular}

Keterangan

1.Menengah: Daerah yang mempunyai potensi Menengah untuk terjadi Gerakan Tanah. Pada Zona ini dapat terjadi gerakan tanah jika curah hujan diatas normal, terutama pada daerah yang berbatasan dengan lembah sungai, gawir, tebing jalan atau jika lereng mengalami gangguan.

2.Tinggi : Daerah yang mempunyai potensi Tinggi untuk terjadi Gerakan Tanah. Pada Zona ini dapat terjadi Gerakan Tanah jika curah hujan diatas normal, sedangkan gerakan tanah lama dapat aktif kembali 
Indikasi atau gejala longsoran diperlihatkan dengan retakan-retakan dan torehan-torehan pada dinding saluran pipa pesat yang disebabkan oleh tekanan masa tanah di bagian atasnya. Berdasarkan hasil penelitian ini telah diperoleh lokasi-lokasi kejadian bencana gerakan tanah/longsoran, sifat keteknikan tanah/batuan, dan pola curah hujan yang memberikan gambaran bahwa curah hujan dengan kumulatif terjadi pada
Bulan Nopember hingga Maret setiap tahunnya yang menimbulkan longsoran di daerah Banjarnegara. Hasil ini diharapkan dapat digunakan sebagai dasar untuk penyusunan strategi mitigasi bencana gerakan tanah dan untuk penataan tata ruang dan pengembangan wilayah di daerah rentan bencana longsoran. Daerah yang termasuk dalam kawasan rawan bencana gerakan tanah yang terdapat di 18 kecamatan dan desa adalah sebagai berikut:

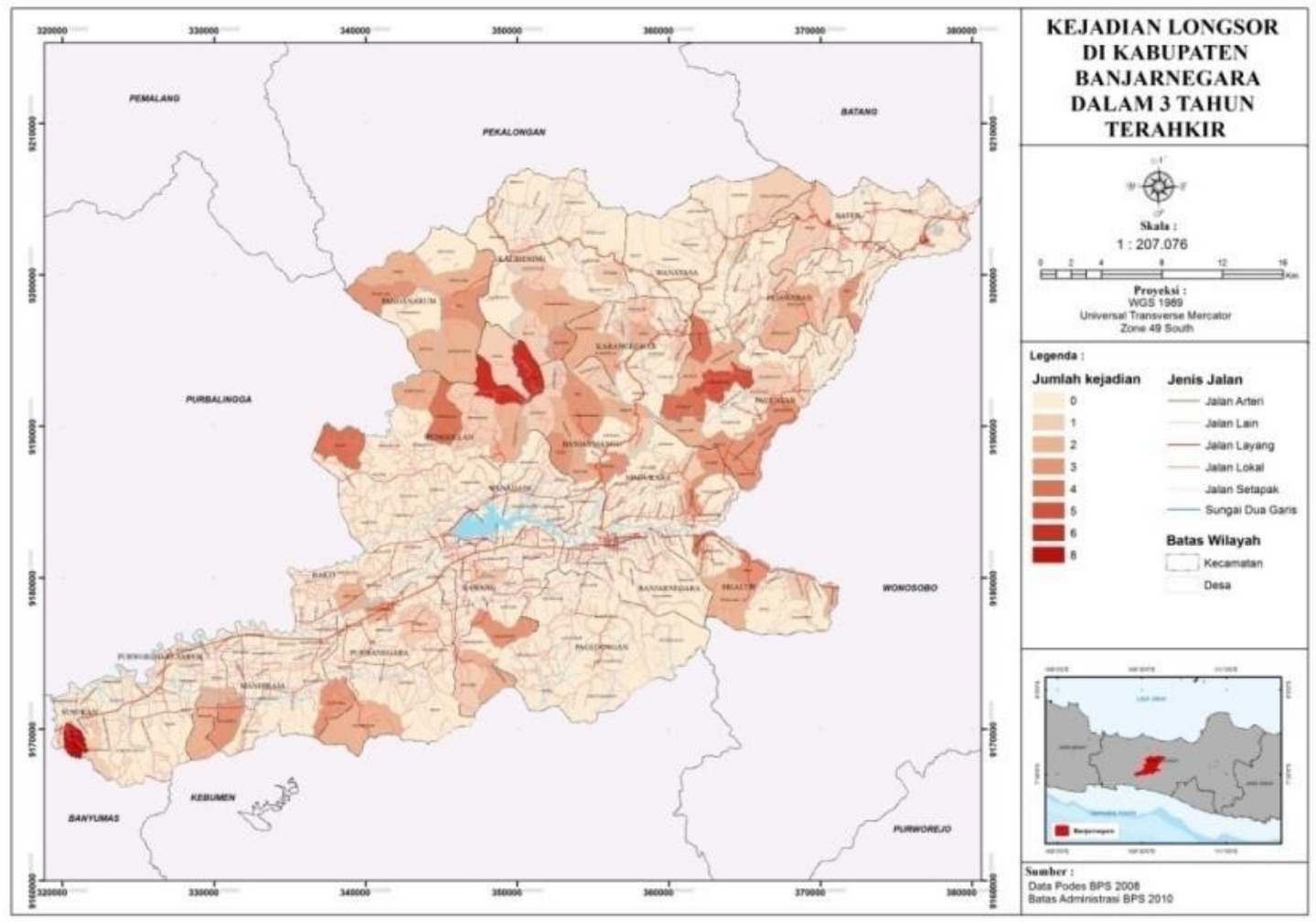

Gambar 10. Peta Kejadian Longsor Kabuaten Banjarnegara

Apabila dilihat dari peta kejadian longsor diatas, maka tampak bahwa Kecamatan Pagenten dan Pandanarum termasuk kecamatan yang beresiko tinggi terhadap bahaya longsor. Hal ini dapat dibuktikan dengan jumlah kejadian longsor yang sering terjadi, terutama di Desa Tlaga (Kec, Pandanarum) dan desa Mundasari dan Desa Suwidak di Kecamatan Pagenten. Kecamatan Wanayasa, Batur, Banjarmangu, Kalibening dan Sigaluh merupakan kecamatan yang termasuk berkatagori sedang dengan 4-6 kejadian longsor rata rata tiap tahunnya. Wilayah yang tergolong ringan kejadian longsornya antara lain di Kecamatan
Pejawaran, Banjarnegara, Pagedongan, Lampok, dan Purwanegara dengan hanya 2-4 kejadian longsor tiap tahunnya.

\section{KESIMPULAN}

Tanah longsor merupakan jenis gerakan tanah. Tanah longsor sendiri merupakan gejala alam yang terjadi di sekitar kawasan pegunungan. Semakin curam kemiringan lereng suatu kawasan, semakin besar pula kemungkinan terjadi longsor. Longsor terjadi saat lapisan bumi paling atas dan bebatuan terlepas dari bagian utama gunung atau bukit. Pada dasarnya sebagian besar wilayah di Indonesia merupakan daerah perbukitan atau 
pegunungan yang membentuk lahan miring. Lahan atau lereng yang kemiringannya melampaui $20^{\circ}$ umumnya berbakat untuk bergerak atau longsor. Tapi tidak selalu lereng atau lahan yang miring berpotensi untuk longsor. Secara garis besar faktor penyebab tanah longsor adalah.a) Kondisi geologi antara lain batuan lapuk, kemiringan lapisan tanah, gempa bumi dan letusan gunung api.b) Iklim yaitu pada saat curah hujan tinggi.c) Keadaan topografi yaitu lereng yang curam. Kecamatan Pagenten dan Pandanarum termasuk kecamatan yang beresiko tinggi terhadap bahaya longsor. Hal ini dapat dibuktikan dengan jumlah kejadian longsor yang sering terjadi, terutama di Desa Tlaga (Kec, Pandanarum) dan desa Mundasari dan Desa Suwidak di Kecamatan Pagenten. Kecamatan Wanayasa, Batur, Banjarmangu, Kalibening dan Sigaluh merupakan kecamatan yang termasuk berkatagori sedang dengan 4-6 kejadian longsor rata rata tiap tahunnya. Wilayah yang tergolong ringan kejadian longsornya antara lain di Kecamatan Pejawaran, Banjarnegara, Pagedongan, Lampok, dan Purwanegara dengan hanya 2-4 kejadian longsor tiap tahunnya.

Sehubungan dengan kondisi fisik wilayah yang bergunung, seyogyanya penataan ruang sangat urgent dilakukan, karena kejadian longsor sangat dapat merenggut banyak korban apabila pada daerah rawan longsor masih banyak permukiman.Upaya pennggulangan longsor, baik secara vegetatif maupun teknis sangat diperlukan

\section{DAFTAR PUSTAKA}

Arsyad Siantala, 1999, Konservasi Tanah Dan Air, IPB Bogor.

Baba Barus, Pemetaan Longsoran Berdasarkan Klasifikasi Statistik Peubah Tunggal Menggunakan SIG: StudiKasus Daerah Ciawi-Puncak-PacetJawa Barat. Jurnal IImu Tanah dan Lingkungan, Bogor.

Edi Prahasta, 2005. Tutorial Arc View, Informatika Bandung

I WayanNuarsa, 2005. Menganalisis Data SpasialDengan Arc View 3.3 Untuk Pemula.Gramedia Jakarta

Samsul Arifin et.al. 2006. Implementasi Penginderaan Jauhdan SIG untuk inventarisasi Daerah RawanLongsordi Propinsi Lampung. Jurnal Penginderaan Jauhdan Pengolahan Data Digital, Jakarta

Sarupin, 2002. Pelestarian Sumberdaya Tanah Dan Air, Andi Offset, Yogyakarta

Sitorus, 2002. Evaluasi Sumber daya Lahan.Tarsito Bandung

Sarwono Hardjowigoeno, 2003. IImu Tanah, AKAPRES Jakarta. 